\title{
DARI ISLAM KE KRISTEN \\ Konversi Agama pada Masyarakat Suku Minangkabau
}

\section{Oleh Kurnial Ilahi, Jamaluddin Rabain, dan Suja'i Sarifandi}

Abstrak: Fenomena konversi agama pada masyarakat suku Minangkabau; dari Penganut Islam menjadi pemeluk Kristen dimulai sejak adanya kontak dan relasi perdagangan antara bangsa-bangsa Barat; Portugis, Belanda, Inggris dan Prancis dengan masyarakat Minangkabau dari Kerajaan Pagaruyung (1347-1825 M). Nama-nama pendeta orang Minang, di antaranya adalah: (1) Pendeta I.F.M. Salim Alias Abdoel Chalid Salim (1904-1985), ia adalah adik kandung Haji Agus Salim, Pahlawan Nasional, (2) Pendeta Willy Amrul alias Abdul Wadud Karim Amrullah disingkat AWKA (1927-2012), adik seayah dari Buya HAMKA, (3) Pendeta Akmal Sani yang sangat besar peranannya dalam merombak Ranah Minang "Adat basandi Syarak, Syarak basandi Kitabullah" menjadi kawasan "Adat dan Syarak basandi Yesus dan Injil,"

Kata Kunci: Kristenisasi, Konversi Agama, Minangkabau 


\section{DARI ISLAM KE KRISTEN \\ Konversi Agama pada Masyarakat Suku Minangkabau}

\section{Oleh Kurnial Ilahi, Jamaluddin Rabain, dan Suja’i Sarifandi}

\section{Pendahuluan}

Manusia sebagai makhluk sosial yang sekaligus juga makhluk individual, memiliki perbedaan antara yang satu dengan yang lainnya. Adanya perbedaan inilah yang menyebabkan mengapa seseorang baik individu ataupun komunitas sosial menyenangi suatu obyek, sedangkan individu ataupun komunitas sosial tidak senang bahkan membenci obyek tersebut. Hal ini sangat tergantung bagaimana individu menanggapi obyek tersebut dengan persepsinya, dan pada kenyataannya sebagian besar sikap, tingkah laku dan penyesuaian manusia ditentukan oleh persepsinya. ${ }^{1}$ Dengan adanya persepsi tersebut akan terbentuk sikap, yaitu suatu kecenderungan yang stabil untuk berlaku atau bertindak secara tertentu di dalam situasi yang tertentu pula. ${ }^{2}$

Islam sebagai agama perdamaian, agama diwahyukan Tuhan kepada masyarakat manusia melalui Nabi Muhammad SAW., yang ajaranajarannya tentang keEsaan Tuhan, persaudaraan umat manusia, dan

${ }^{1}$ Persepsi merupakan suatu proses yang didahului oleh penginderaan. Kemudian penginderaan merupakan suatu proses diterimanya stimulus oleh individu melalui alat penerima, yaitu alat indera. Namun proses tidak berhenti pada tahap ini. Pada umumnya, stimulus diteruskan oleh saraf sensorik ke otak sebagai pusat susunan saraf dan proses selanjutnya merupakan proses persepsi, yaitu orang menyadari apa yang diinderanya. Bimo Walgito, Pengantar Psikologi Umum, (Yogyakarta: Andi Offset, 2007), hlm. 25.

${ }^{2}$ W.A. Gerungan, Psikologi Sosial, (Bandung: Eresco, 1980), hlm. 137. Lihat Mar'at, Sikap Manusia, Perubahan serta Pengukurannya, (Jakarta: Ghalia Indonesia, 1981), hlm. 11. 
mencakup berbagai aspek kehidupan. ${ }^{3}$ Di kalangan masyarakat Eropa Barat/ Kristen pada umumnya dipersepsikan negatif, ${ }^{4}$ di sisi lain beberapa tokoh masyarakat yang nota benenya beragama Kristen dari kalangan Elit, Pastur, Pendeta, Dosen dan lain-lain justeru meninggalkan agama Kristen, berpindah/konversi agama dan memilih Islam sebagai agama baru mereka. ${ }^{5}$ Ketika di Eropa - Barat, fenomena konversi agama telah terjadi kalangan Elit, Pastur, Pendeta, Dosen dan lain-lain dari

${ }^{3}$ Harun Nasution, Islam Ditinjau Dari Berbagai Aspeknya, (Jakarta : Bulan Bintang, 1991), Juz I, hlm. 9. Maulana Muhammad Ali, Islamologi (Din al-Islam), Terjemahan, PT. (Jakarta: Ikhtiar Baru Van Hoeve, 2000), hlm. 2.

${ }^{4}$ Maxime Rodinson, Europe and the Mystique of Islam, (London : LB. Tauris \& Co, 1988), dalam google_book, 2014, hlm. 3. Sebagaimana menurut cendekiawan terkemuka Prancis, Maxime Rodinson dikatakan bahwa umat Kristen di Barat mempersepsi dunia Muslim sebagai bahaya, jauh sebelum Islam dilihat sebagai masalah nyata. Pandangan ini disepakati oleh sejarawan Inggris Albert Hourani, yang berpendapat bahwa Islam sejak awal kemunculannya merupakan masalah bagi Eropa yang Kristen. Memandang Islam dengan campuran ketakutan dan ketidakmengertian, bangsa Kristen tidak bisa menerima kenabian Muhammad SAW., ataupun kesejatian wahyu yang diturunkan kepadanya. Hal yang paling luas diyakini umat Kristen, menurut Hourani, ialah bahwa "Islam adalah agama palsu, Allah bukanlah Tuhan, Muhammad bukan seorang nabi; Islam dikarang oleh orang-orang yang berniat dan berwatak buruk, serta didukung kekuatan pedang." Albert Hourani, Islam in European Thought (New York: Cambridge University Press, 1991), dalam google_book, 2015, hlm. 7-8, 10.

${ }^{5}$ Menurut data Harian The Independent, Selasa 4 Januari 2011 dilaporkan bahwa jumlah muallaf di Inggris terus bertambah sampai dengan tahun 2010, tercatat sebanyak 100 ribu Muslim baru di negeri ini. Dari segi gender, kebanyakan muallaf adalah perempuan kulit putih usia 20-30 tahunan. tahun 2011 tercatat sebanyak 3.466 atau dua pertiga dari jumlah keseluruhan mualaf (5.200 orang) perempuan kulit putih Inggris yang menjadi mualaf. Mereka umumnya mengaku muak dengan imoralitas dan konsumerisme Inggris. Berdasar angka ini, organisasi itu menyebut tengah terjadi gelombang "Islamifikasi" di Inggris. Survei mengungkapkan, hampir dua pertiga muallaf adalah perempuan, lebih dari 70 persen adalah kulit putih dan usia rata-rata pada saat konversi iman adalah 27 tahun. Namun, selain mengaku muak dengan imoralitas dan konsumerisme, beberapa beralasan bahwa Islam lebih kompatibel bagi Inggris. Konversi menjadi Muslim bukan tentang tekad untuk merusak cara hidup Barat. Ini hanya sekelompok orang normal yang bersatu dalam kepatuhan mereka untuk agama yang mereka, dan untuk sebagian besar dari mereka melihat Islam sebagai kompatibel dengan kehidupan Inggris. Aal Nur Alamsyah, "Eropa Sedang di Jangkiti Virus Islamfobia, Mualaf Justru malah Bertambah,” dalam Islamic-defenders.blogspot.com/2013/03/eropa-sedang-dijangkiti-virus.html, Diakses Tanggal 09 Maret 2014. 
agama Kristen berpindah agama/konversi agama dan memilih Islam sebagai agama baru mereka, justeru di Indonesia fenomena tersebut mulai terjadi dalam kehidupan bangsa, masyarakat dan suku yang nota benenya fanatik sebagai penganut Islam seperti yang terjadi masyarakat suku Melayu dan masyarakat suku Minangkabau. Dalam konteks ini Sarah Mantovani, menulis :

Suku Minangkabau di Sumatera Barat dengan falsafah adatnya yang "Adaik Basandi Syarak, Syarak Basandi Kitabullah" (ABSSBK) selama ini telah dikenal dengan daerah keislamannya yang kental. Falsafah adat yang bersendikan syariat Kitabullah (alQur'an). Bukan hanya sekedar pepesan kosong biasa, melainkan telah berurat berakar ke dalam diri masyarakatnya. Maka tidak heran, jika dengan falsafah adatnya tersebut, keislaman masyarakat suku Minangkabau begitu kuat dan Sumatera Barat menjadi daerah yang sulit ditaklukkan untuk dikristenkan setelah Aceh. Namun seiring dengan perkembangan zaman dan bergesernya nilai-nilai adat, masyarakat suku Minangkabau di Sumatera Barat seperti tidak lagi sulit untuk dikristenkan, terlebih dengan cara-cara pengkristenisasiannya kini semakin canggih dan menggunakan cara yang sangat halus sehingga secara tidak sadar masyarakat telah dikristenkan. ${ }^{6}$

Sebagai contoh, seorang Pendeta bernama Yanwardi Koto. Asal Lubuk Basung, Agam, Sumatera Barat, adalah asli orang Minang telah banyak memurtadkan warga Minangkabau, baik di pelosok dan maupun di kota, yang berakibat penurunan jumlah umat Islam sebagaimana data sebagai berikut :

Data BPS 2010 menjelaskan adanya penurunan yang sangat signifikant jumlah umat Islam di Kecamatan Koto Tangah Padang Sumatera Barat, Jumlah Umat Islam dari 164.675 orang tahun 2009 menjadi 158.469 orang umat Islam tahun 2010 berkurang sebanyak 6206 orang dalam jangka waktu 1 tahun, sementara Agama lain

${ }^{6}$ Sarah Mantovani, Kristenisasi Cengkeram Ranah Minang, dalam http://www. academia.edu/4382836/Hidayatullah_Kristenisasi_Cengkeram_Ranah_Minang, Dikases Tanggal 25 Maret 2016. 
mengalami peningkatan yang sangat significant, Agama Katolik dari 310 orang tahun 2009 menjadi 1.065 tahun 2010 naik 755 orang dalam 1 tahun, Agama Protestan dari 975 tahun 2009 menjadi 2.376 tahun 2010, naik 1401 orang dalam jangka 1 tahun. ${ }^{7}$

Konversi agama secara umum dapat diartikan dengan berubah agama ataupun masuk agama. Konversi agama banyak menyangkut masalah kejiwaan dan pengaruh lingkungan tempat berada. Selain itu konversi agama yang dimaksud juga mempunyai beberapa pengertian dengan ciriciri sebagai berikut :

(1) Adanya perubahan arah pandangan dan keyakinan seseorang terhadap agama dan kepercayaan yang dianutnya, (2) perubahan yang terjadi dipengaruhi kondisi lingkungan sehingga perubahan dapat terjadi secara berproses atau secara mendadak, (3) perubahan tersebut bukan hanya berlaku bagi perpindahan kepercayaan dari suatu agama ke agama lain tetapi juga termasuk perubahan pandangan terhadap agama yang dianutnya sendiri, (4) selain faktor kejiwaan dan kondisi lingkungan, maka perubahan itu pun disebabkan faktor petunjuk dari Yang Maha Kuasa. ${ }^{8}$

Adapun faktor-laktor yang mempengaruhi terjadinya konversi agama adalah sebagai berikut :

(1) Faktor keluarga; keretakan keluarga, ketidakserasian, berlainan agama, kesepian, kesulitan seksual, kurang mendapatkan pengakuan kaum kerabat lainnya. Kondisi yang demikian menyebabkan seseorang akan mengalami tekanan batin yang menimpa dirinya, (2) Faktor lingkungan tempat tinggal; orang yang merasa terlempar dari lingkungan tempat tinggal atau tersingkir dari kehidupan di suatu tempat merasa dirinya hidup sebatang kara. Keadaan yang demikian menyebabkan seseorang mendambakan ketenangan dan mencari tempat untuk bergantung hingga kegelisahan batinnya hilang,

${ }^{7}$ Admin, Geliyat Kristenisasi Di Ranah Minang, dalam https://cahyaimancahayakebenaranislamwordpress.com/2013/11/16/geliyat-kristenisasi-diranah-minang/, Dikases Tanggal 25 Maret 2016.

${ }^{8}$ Mukti Ali, dkk., Agama Dalam Pergumulan Masyarakat Kontemporer, (Yogyakarta, Tiara Wacana, 2001), hlm. 30. 
(3)Faktor perubahan status; perubahan status terutama yang berlangsung secara mendadak akan banyak mempengaruhi terjadinya konversi agama, misalnya; perceraian, keluar dari sekolah ataupun perkumpulan, perubahan pekerjaan, kawin dengan orang yang berlainan agama dan sebagainya, (4) Faktor kemiskinan; kondisi sosial ekonomi yang sulit juga merupakan faktor yang mendorong dan mempengaruhi terjadinya konversi agama. Masyarakat awam yang miskin cenderung untuk memeluk agama yang menjanjikan kehidupan dunia yang lebih baik. Kebutuhan mendesak akan sandang dan pangan dapat mempengaruhi, dan (5) Faktor pendidikan; dalam hal ini literatur ilmu sosial menampilkan argumentasi bahwa pendidikan memainkan peranan lebih kuat atas terbentuknya disposisi religius yang lebih kuat bagai kaum wanita dari pada kaum pria. Lebih lanjut ditemukan fakta dari pendirian sekolah-sekolah keagamaan yang dipimpin oleh Yayasan-yayasan berbagai agama. Kenyataan menunjukkan bahwa sebagian kecil saja dari seluruh jumlah anak didik dari sekolah tersebut masuk agama yang dipeluk pendirinya. Hanya sejauh itu dapat dibenarkan sistem pendidikan lewat persekolahan termasuk faktor pendorong masuk agama. ${ }^{9}$

Selain itu interaksi antara aspek-aspek keagamaan sulit dipisahkan dengan aktivitas-aktivitas sosial yang lain, sehingga aspek-aspek keagamaan tersebut dapat melahirkan makna sosial tertentu dalam manivestasinya, di mana salah satu wujud dari perkembangan agama pada seseorang di antaranya adalah terjadinya tindakan konversi agama. Menurut Ahli pendidikan bahwa kondisi pendidikan juga bisa mempengaruhi terjadinya konversi agama. Hal ini terjadi pada sebagian masyarakat dengan adanya anak didik yang disekolahkan dalam naungan yayasan milik agama tertentu tidak harus menganut agama yang sama. Walaupun hal ini belum terbukti, tetapi tidak secara langsung tujuan yang hendak dicapai sangat besar dalam mempengaruhi pola pikirnya karena kondisi pendidikan kembali menjadi faktor yang cukup efisien dapat mempengaruhi pola pikir seseorang akibat interaksi berkepanjangan

${ }^{9}$ Ibid., hlm. 31-32. 
dengan keyakinan yang berlainan. Pengalaman keagamaan bersikap harapan-harapan, perasaan-perasaan dan persepsi-persepsi pemeluknya ketika berkomunikasi dengan Tuhan sebagai supranatural Yang Maha Suci sebagai pengalaman objektif dan tanda keagamaan individual. Pengalaman keagamaan seseorang, sebab pengalaman keagamaan sekaligus dapat merupakan pengetahuan keagamaan yang mengacu pada harapan bahwa orang beragama minimal mempunyai pengetahuan tentang prinsip, prinsip keyakinan, kitab suci, tata cara dan tradisi keagamaan. ${ }^{10}$

\section{Landasan Konseptual Konversi Agama}

Dalam Kamus Umum Bahasa Indonesia, kata konversi diartikan sebagai perubahan dari satu sistem pengetahuan ke sistem yang lain, perubahan dari satu bentuk, rupa dan sebagainya ke bentuk, rupa yang lain. ${ }^{1}$ Sedangkan agama dapat diartikan sebagai suatu keta'atan atau penyerahan diri kepada kekuatan yang lebih tinggi (gaib) dari manusia, yang dipercaya mengatur dan mengontrol, mengatur jalan alam dan kehidupan manusia. ${ }^{2}$ Kata konversi berasal dari bahasa latin conversion, yang berarti taubat, pindah, berubah. ${ }^{3}$ Dalam bahasa Inggris conversion, yang mengandung pengertian berubah dari suatu keadaan, atau dari suatu agama ke agama lain (change from state of from one religion to another). ${ }^{4}$ Dengan demikian, konversi agama (religious conversion) secara umum dapat diartikan dengan berubah agama ataupun masuk agama, bertaubat, berubah agama, berbalik pendirian terhadap ajaran agama atau masuk ke dalam agama, suatu perubahan kepercayaan dan keta'atan terhadap suatu agama yang dianut oleh seseorang, melepaskan kepercayaan terhadap suatu agama dan memeluk atau mempercayai agama lain. Lebih tegasnya, konversi agama dapat disebut pindah agama, misalnya dari seorang

\section{${ }^{10}$ Ibid., hlm. 8.}

${ }^{1}$ Tim Penyusun Diknas RI, Kamus Umum Bahasa Indonesia, (Jakarta : Balai Pustaka, 2001), hlm. 592.

${ }^{2}$ Hasan Ali, Ilmu Perbandingan Agama, (Yogyakarta : al-Falah, 1995), hlm. 6.

${ }^{3} J a l a l u d d i n$, Psikologi Agama, (Jakarta: Raja Grafindo, 1996), hlm. 245.

${ }^{4}$ D. Hendro Puspito, Sosiologi Agama, (Yogyakarta: Kanisius, 1993), hlm. 79. 
pemeluk agama Kristen menjadi pemeluk agama Islam, atau sebaliknya, dan bisa juga perubahan keta'atan terhadap sesuatu agama.

Secara terminologi konversi agama memiliki beberapa pengertian, di antaranya menurut Thouless, konversi agama adalah istilah yang pada umumnya diberikan untuk proses yang menjurus kepada penerimaan suatu sikap keagamaan, proses itu bisa terjadi secara berangsur-angsur atau secara tiba-tiba. Menurut kata "convertion" dalam bahasa Inggris berarti "masuk agama." Sementara Max Heirich mendeskripsikan konversi agama adalah tindakan seseorang atau kelompok yang masuk atau berpindah ke suatu system kepercayaan atau perilaku yang berlawanan dengan kepercayaan yang sebelumnya. ${ }^{6}$ Konversi agama banyak menyangkut masalah kejiwaan dan pengaruh lingkungan tempat berada, yang memuat beberapa pengertian dengan ciri-ciri sebagai berikut:

a. Adanya perubahan arah pandangan dan keyakinan seseorang terhadap agama dan kepercayaan yang dianutnya,

b. Perubahan yang terjadi dipengaruhi kondisi kejiwaan sehingga perubahan secara berproses atau secara mendadak,

c. Perubahan tersebut bukan hanya berlaku bagi perpindahan kepercayaan dari suatu agama ke agama lain, tetapi juga termasuk perubahan pendangan terhadap agama yang dianutnya sendiri.

d. Selain faktor kejiwaan dan kondisi lingkungan maka perubahan itupun disebabkan faktor petunjuk dari yang maha kuasa. ${ }^{7}$

Menurut Zakiyah Daradjat, konversi agama (Inggris: conversion) berarti berlawanan arah, yang dengan sendirinya konversi agama berarti terjadinya suatu perubahan keyakinan yang berlawanan arah dengan keyakinan semula. ${ }^{8}$ Maksud yang sama tetapi dengan penterjemahan kata konversi agama sebagaimana dikutip oleh Jalaluddin adalah suatu

${ }^{5}$ Ibid., 80.

${ }^{6}$ Max Heinrich, Change Of Heart: A Test of Some Widely Theories about Religious Conversion, dalam American Journal Of Sociologi, Volume 83, Nomor 3, hlm. 667.

${ }^{7}$ Ibid., hlm. 668.

${ }^{8}$ Zakiyah Daradjat, Ilmu Jiwa Agama, (Jakarta: PT. Bulan Bintang, 2005), hlm. 137. 
tindakan di mana seseorang atau kelompok orang yang masuk atau berpindah ke suatu sistem kepercayaan atau perilaku yang berlawanan arah dengan kepercayaan sebelumnya. Oleh karena itu mempunyai dua pengertian, pindah dari suatu agama ke agama yang lain atau pindah dari suatu tingkatan pendalaman dalam satu agama ke tingkatan yang lebih tinggi, yaitu dari keadaan belum memahami menjadi memahami dan melaksanakan. ${ }^{9}$ Walter Houston Clork dalam The Psychology of Religion memberikan definisi sebagai berikut:

Konversi agama sebagai pertumbuhan atau perkembangan spiritual yang mengandung perubahan arah yang cukup berarti dalam sikap terhadap ajaran dan tindakan agama. Lebih jelas dan tegas lagi konversi agama menunjukkan bahwa suatu perubahan emosi yang tiba-tiba ke arah mendapat hidayah Allah SWT secara mendadak, telah terjadi yang mungkin saja sangat mendalam atau dangkal, dan mungkin pula terjadi perubahan tersebut secara berangsur-angsur. ${ }^{10}$

Istilah konversi agama ada dua madzhab. Pertama, makna konversi sesuai asal bahasa yakni perubahan. Semua perubahan disebut konversi, baik itu perubahan keyakinan dari Islam ke non Islam ataupun dari non Islam ke Islam yang jelas mengalami perubahan agama. Konversi agama juga banyak menyangkut masalah psikologi (kejiwaan) manusia dan pengaruh lingkungan dimana manusia berada. Konversi agama yang dimaksud selain uraian di atas memiliki beberapa pengertian, yaitu:

a. Terjadinya perubahan pandangan dan keyakinan seseorang terhadap agama dan kepercayaan yang dianutnya.

b. Perubahan yang terjadi dipengaruhi oleh kondisi kejiwaan sehingga perubahan dapat terjadi secara berproses atau secara mendadak.

c. Perubahan tersebut bukan hanya berlaku bagi perpindahan kepercayaan dari suatu agama ke agama lain,. tetapi ,juga termasuk perubahan pandangan terhadap agama yang dianutnya sendiri.

${ }^{9}$ D. Hendro Puspito, op. cit., hlm. 80.

${ }^{10}$ Zakiyah Drajat, op. cit., hlm. 138. 
d. Faktor kejiwaan dan kondisi lingkungan makna perubahan selain itu juga disebabkan oleh faktor petunjuk dari Tuhan Yang Maha Kuasa. ${ }^{11}$

Dengan pengertian konversi agama di atas, secara jelas menekankan pada peristiwa perpindahan atau perubahan pemahaman, loyalitas keyakinan yang ditinggalkan dinilai salah, dan yang baru merupakan yang benar. Namun, pada dasarnya tindakan konversi agama sama halnya dengan fakta-fakta psikis lainnya, dan tidak dapat diteliti secara langsung proses terjadinya konversi agama tersebut, dan keyakinan secara mendadak itu yang diawali oleh konflik batin dan perhelatan jiwa yang sangat panjang dalam perjalanan hidupnya.

\section{Konversi Agama Pada Masyarakat Suku Minangkabau}

Ketika Belanda membangun sarana pendidikan/ sekolah-sekolah dan rumah sakit, fasilitas ini oleh para misionaris, zending, pendeta dan pastur dimanfaatkan untuk mengajak penduduk pribumi/ masyarakat suku Minangkabau berpindah agama menjadi pemeluk Kristen. Namun ternyata masyarakat Minangkabau tidak gampang dimasuki, karena telah terjalin sebuah sistem budaya ikatan simbiotik yang erat antara adat dan Islam dengan falsafah adatnya "Adaik Basandi Syarak - Syarak Basandi Kitabullah" (ABS-SBK), ${ }^{11}$ sehingga belum ada masyarakat dari suku Minangkabau yang menjadi pemeluk Kristen ketika itu. Dalam konteks ini Sarah Mantovani, menulis :

Suku Minangkabau di Sumatera Barat dengan falsafah adatnya yang "Adaik Basandi Syarak, Syarak Basandi Kitabullah" (ABS-SBK) selama ini telah dikenal dengan daerah keislamannya yang kental. Falsafah adat yang bersendikan syariat Kitabullah (al-Qur'an). Bukan hanya sekedar pepesan kosong biasa, melainkan telah berurat berakar ke dalam diri masyarakatnya. Maka tidak heran, jika dengan falsafah adatnya tersebut, keislaman masyarakat suku Minangkabau

${ }^{11}$ Jalaluddin, op. cit., hlm. 246.

${ }^{11}$ Mardjamni Martamin, et.al, op. cit., hlm. 125. 
begitu kuat dan Sumatera Barat menjadi daerah yang sulit ditaklukkan untuk dikristenkan setelah Aceh. ${ }^{12}$

Akhirnya yang menjadi incaran mereka adalah para pendatang, khususnya etnis Cina, suku Mentawai, suku Batak, Nias dan Jawa. Orang Cina berhasil terpedaya untuk memasukkan anak-anak mereka ke sekolah kristen, karena demikian, banyak dari anak-anak mereka yang masuk menganut agama Kristen. Frater Padang adalah salah satu lembaga pendidikan Kristen yang paling berjasa dalam hal ini. Didirikan pada tahun 1823 oleh Rater Paulus Jacobs, Severinus Aarts, Hermenigildus Fromm, Theodatus Van Oers dan Claudius Kok. Dalam sejarahnya, selain Katolik dan Protestan, di Ranah Minang juga tersebar ajaran Gereja Masehi Advent Hari Ketujuh, Bethani, Pantekosta, Katedral, ${ }^{13}$ dan lain-lain.

Seiring dengan perkembangan zaman dan bergesernya nilai-nilai adat, masyarakat Sumatera Barat seperti tidak lagi sulit diajak berpindah agama menjadi pemeluk Kristen, terlebih cara-cara kristenisasi dewasa ini semakin canggih dan menggunakan cara yang sangat halus sehingga secara tidak sadar masyarakat telah dikristenkan. Para misionaris, zending, pendeta dan pastur tidak berhenti sampai di situ saja, mereka terus bergerak dengan cara yang hebat dan dengan dukungan dana yang banyak. Gerakan kristenisasi di Ranah Minang semakin menampakkan hasil sejak tahun 1950-an, yaitu melalui beberapa orang Pemuda Minangkabau yang berada di Singapura. Mereka telah lebih dulu masuk Kristen. Ketika pulang ke kampung, mereka melakukan pengabaran injil dan membujuk anak-anak muda Minang untuk berpindah agama menjadi pemeluk Kristen. Cara-cara yang dilakukan ternyata berhasil membawa beberapa orang pemuda Minang masuk Kristen. Kelompok inilah yang pertama masuk Kristen, tetapi itu pun tidak lama bertahan, mereka kembali masuk Islam karena motifnya tidak lebih dari sikap

${ }^{12}$ Sarah Mantovani, Kristenisasi Cengkeram Ranah Minang, dalam http://www.academia.edu/4382836/Hidayatullah_Kristenisasi_Cengkeram_Ranah_Minang, Dikases Tanggal 25 Maret 2016.

${ }^{13}$ Sumber : Buletin Jum'at Barito Minang, (Edisi: 08 Tahun II / 1 Jumadil Ula 1436 H / 20 Februari 2015 M). 
pragmatis. Kondisi ekonomi yang serba sulit, kemudian dijanjikan hal-hal yang sangat kontra-produktif dengan sikap dasar orang Minang, lama kelamaan tujuan misi terungkap sehingga banyak di antara mereka yang menyatakan keluar dan kembali lagi kepada Islam. ${ }^{14}$

Gerakan kristenisasi semakin jelas dan meningkat sejak tahun 1950an, seiring dengan adanya program transmigrasi di Obilin dan Swahlunto. Bersamaan dengan itu, misi kristenisasi juga dilakukan melalui asimilasi masyarakat Minang melalui perkawinan. Namun, pendekatan ini ditolak secara mentah-mentah oleh masyarakat Minang, bahkan menimbulkan reaksi keras dari berbagai kalangan. Meskipun demikian masih ada yang berhasil dibawanya. Gerakan tersebut semakin gencar dilakukan, bahkan tidak pandang bulu. Seiring dengan itu, pendirian gereja pun semakin gencar dilakukan di tengah-tengah komunitas umat Islam, tambah lagi dengan menjamurnya unit-unit pelayanan sosial, kemanusiaan dan kesehatan.

Pada tahun 1970-an proyek kristensisasi dilakukan dengan cara mendirikan Rumah Sakit Baptis Immanuel di Bukittinggi, akan tetapi misi mereka cepat tercium dan akhirnya ditolak. ${ }^{15}$ Keberhasilan menggagalkan proyek kristensisasi di ranah Minang tidak terlepas dari peran semua komponen masyarakat Minang, terutama Buya H. M. D. Dt. Palimo Kayo, mantan Ketua MUI Sumbar, Buya Mohd. Natsir, Buya Hamka, mantan Ketua MUI Pusat. Untuk menghambat gerakan kristenisasi di ranah Minang, di Bukit Tinggi telah dibangun Rumah Sakit Islam Ibnu Sina dan Rumah Sakit Immanuel diambil alih oleh pemerintah dengan mengubah nama dan statusnya menjadi Rumah Sakit Ahmad Mukhtar.

Selain melalui cara-cara tersebut, perantaraan ekonomi proyek Kristenisasi juga kerap kali dilakukan di Ranah Minang. Usaha yang dilakukan Koppasta (Koperasi Pasar Tarusan) dan Bank Lippo milik James T. Riady adalah contoh yang belum bisa dilupakan dari dalam

${ }^{14}$ Sumber : Buletin Jum'at Barito Minang, (Edisi: 08 Tahun II / 1 Jumadil Ula 1436 H / 20 Februari 2015 M).

${ }^{15}$ Sumber : Buletin Jum'at Barito Minang, (Edisi: 08 Tahun II / 1 Jumadil Ula 1436 H / 20 Februari 2015 M). 
ingatan orang Minang. Dalam wawancara dengan mantan Ketua PW. PII Sumbar, Cendra Hardi Nurba, dijelaskan bahwa Koppasta merupakan lembaga simpan pinjam yang diperuntukkan khusus bagi umat Islam di Tarusan, Painan. Koperasi ini langsung berada di bawah pimpinan seorang Katolik, tetapi akhirnya usaha ini diketahui masayarakat Painan. ${ }^{16}$

Sementara Bank Lippo sebagaimana dijelaskan Dalam wawancara mendalam dengan ulama dan tokoh masyarakat Sumatra Barat, ${ }^{17}$ bahwa Bank Lippo khusus diperuntukkan bagi muslim yang berada di daerah perkotaan. Terungkapkan bahwa langkah kedua lembaga ini nampak seiring, sama-sama bergerak pada simpan pinjam. Modus ini sepintas tidak beda dengan lembaga simpan pinjam dan keuangan lainnya, tetapi misinya baru terlihat setelah didalami secara baik. ${ }^{18}$

Pasca gempa Sumatera Barat tahun 2009 yang lalu, dalam situs Hizbut-Tahrir Indonesia menyebutkan, bahwa Misionaris Kristen menggunakan bendera LSM Mitra Sejati dan Samaritan telah membagibagikan alkitab yang berjumlah sekitar 180 buah dan mengajak masyarakat suku Minangkabau masuk Kristen. Kejadian ini terjadi di Korong Koto Tinggi, Kecamatan V Koto Timur, Kabupaten Padang Pariaman. ${ }^{19}$ Berbagai cara lainnya yang dilakukan oleh para missionaris untuk memurtadkan masyarakat suku Minangkabau agar berpindah agama dari Islam ke Kristen adalah melalui perkawinan, bantuan sosial

${ }^{16}$ Cendra Hardi Nurba, Ketua PW. PII Sumatra Barat, Wawancara, Padang, 14 Oktober 2016.

${ }^{17}$ Tengku Rahman, Ulama Kumpulan- Bonjol - Bukit Tinggi, Wawancara Mendalam, di Kumpulan- Bonjol - Bukit Tinggi, 19 November 2016. Zulfikar, Kepala Seksi Bimbingan Masyrakat Islam Kota Bukit Tinggi, Bukit Tinggi 16 Oktober 2016. Syafrijon, Ketua Majelis Ulama (MUI) Kabupaten Lima Puluh Kota, Wawancara Mendalam, Tanjung Sati, 15 Oktober 2016. Ibnu D. Ghani, Ketua Lembaga Pagar Nagari dan Pembina Rumah Muallaf Sumatra Barat, Wawancara Mendalam, Padang 16 Oktober 2016. Syahidul Amin, Kepala Seksi Bimbingan Masyrakat Islam Kota Bukit Tinggi, Wawancara, Padang Panjang, 16 Oktober 2016.

${ }^{18}$ Ibnu Aqil D. Ghani, Ketua Pagar Negeri Sumatra Barat dan Ketua Lembaga Muallaf Center Sumatra Barat, Wawancara, Padang, 14 Oktober 2016.

${ }^{19}$ Admin, "Misionaris Kristen menggunakan bendera LSM Mitra Sejati dan Samaritan membagi-bagikan Alkitab," dalam http://www.hidayatullah.com, Diakses Tanggal 15 November 2016. 
ekonomi, hipnotis, sihir, penculikan dan pemerkosaan, serta menjadikan al-Qur'an dan Hadis sebagai alat kristenisasi. ${ }^{20}$

Ketika dilakukan wawancara mendalam dengan ulama dan tokoh masyarakat suku Minangkabau, ${ }^{21}$ dan didukung dengan sumber dokumentasi, diketahui bahwa proyek kristenisasi di Sumatera Barat sudah berjalan sejak jaman penjajahan Belanda sampai dengan sekarang. Hal ini sangat menarik, karena sampai hari ini tercatat sudah 623 orang dari suku Minangkabau yang sudah dikristenkan sejak tahun 2000-2005, dan sampai dengan tahun 2012 sebagaimana dilaporkan oleh Persekutuan Gereja Indonesia (PGI), bahwa orang Minangkabau yang sudah berpindah agama dari Islam menjadi pemeluk Kristen telah mencapai 30.000 jiwa yang tersebar di seluruh penjuru dunia. ${ }^{22}$ Dari jumlah tersebut, tercatat sudah ada 30 orang dari suku Minangkabau yang telah menjadi pendeta, dan aktif dalam proyek kristensisasi di ranah Minang dan pada masyarakat suku Minangkabau di seluruh dunia. Berikut ini dapat dikemukakan beberapa nama orang Minangkabau yang sudah menjadi pendeta adalah:

${ }^{20}$ Ibnu Aqil D. Ghani, dkk., Fakta dan Data Pemurtadan; Minangkabau di Bawah Genggaman Pemurtadan Kristenisasi Gaya Dzalim, Pola Jin dan Hipnotis, (Padang : Penerbit Gerakan Anti Pemurtadan, 2003), hlm. 3. Hartono Ahmad Jaiz, Fakta dan Data Pemurtadan; Al-Qur'an Dijadikan Sebagai Alat Kristenisasi, (Padang : Penerbit Surau, 2003), hlm. 1-3.

${ }^{21}$ Tengku Rahman, Ulama Kumpulan- Bonjol - Bukit Tinggi, Wawancara Mendalam, di Kumpulan- Bonjol - Bukit Tinggi, 19 November 2016. Zulfikar, Kepala Seksi Bimbingan Masyrakat Islam Kota Bukit Tinggi, Bukit Tinggi 16 Oktober 2016. Syafrijon, Ketua Majelis Ulama (MUI) Kabupaten Lima Puluh Kota, Wawancara Mendalam, Tanjung Sati, 15 Oktober 2016. Ibnu D. Ghani, Ketua Lembaga Pagar Nagari dan Pembina Rumah Muallaf Sumatra Barat, Wawancara Mendalam, Padang 16 Oktober 2016. Syahidul Amin, Kepala Seksi Bimbingan Masyrakat Islam Kota Bukit Tinggi, Wawancara, Padang Panjang, 16 Oktober 2016.

${ }^{22}$ Admin, "Tahun 2012, Orang Minangkabau Sudah Murtad Mencapai 30.000 Jiwa," dalam https://www.google.com/search?client=firefox-

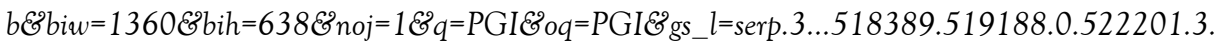
3.0.0.0.0.0.0.0.......1c.1.64.serp..3.0.0.CAEL-R4Nirc, Diakses Tanggal 20 November 2012. 
Pertama, Pendeta I.F.M. Salim Alias Abdoel Chalid Salim (Adik Haji Agus Salim, Pahlawan Nasional). ${ }^{23}$ Abdoel Chalid Salim dilahirkan di Tanjung Pinang (Kepulauan Riau), pada 24 November 1902. Awalnya ia seorang muslim, kemudian menjadi komunis (masuk PKI) dan akhirnya pindah ke agama Kristen Katolik dan menjadi Penginjil, berganti nama menjadi Ignatius Franciscus Michael Salim (disingkat: I.F.M. Salim). ${ }^{24}$ Ayahnya berasal Koto Gadang, Sutan Muhammad Salim, pernah bertugas di kota 'dollar' Kepulauan Riau sebagai seorang Hoofdd Jaksa dalam jajaran Departemen BB Belanda yang sudah ditugaskan di banyak tempat, termasuk di Padang dan Medan. Abdoel Chalid Salim tidak sempat mengenal ibunya karena sang ibu meninggal ketika ia masih bayi. Ayahnya kemudian menikah lagi dengan Widna Roemaniah.

Abdoel Chalid Salim memiliki 13 orang bersaudara, tapi hanya 7 orang yang berumur panjang, yang tertua adalah Haji Agus Salim yang kemudian menjadi diplomat kawakan Indonesia, republik balita yang baru lepas dari hisapan mencucut 'palasik kuduang' Belanda. Chalid mengatakan dalam otobiografinya, Vijftien Jaar Boven-Digoel (1973) bahwa keluarganya sehari-hari di rumah berkomunikasi dalam bahasa Belanda karena ayahnya termasuk golongan elit pribumi dalam sistem administrasi kolonial Hindia Belanda. Chalid bersekolah di MULO Batavia tahun 1923, mengikuti ayahnya yang memilih tinggal di ibukota Hindia Belanda itu setelah pensiun. Setelah itu ia berkerja di onderneming Soember Moedjoer di Lumajang. Kemudian ia mengikuti saudaranya, Jacob Salim, di Pontianak. Di sana ia menjadi anggota redaksi Halilintar Hindia, sebuah berkala yang menjadi corong PKI, dan mendirikan Partai Sarekat Rakyat dengan Koesno Goenoko.

${ }^{23}$ Suryadi, "Chalid Salim ; Dari Simpatisan PKI ke Kayu Salib," dalam http://niadilova.blogdetik.com/index.php/archives/1051,

dan https://maharadjo.wordpress.com/2015/10/21/chalid-salin-dari-simpatisan-pki-ke-kayu-salib/, Tanggal 15 November 2016.

${ }^{24}$ Admin, "Pemurtadan di Minangkabau," dalam https://soeloehmelajoe.wordpress.com/2013/10/29/pemurtadan-di-minangkabau/, Diakses Tanggal 15 November 2016. 
Kemudian Abdoel Chalid Salim kembali ke Jawa dan menepat ke Surabaya. Di sana ia bertemu dengan Moeso dan menjadi anggota redaksi berkala merah Proletar. Tahun 1925 Pemerintah Kolonial Belanda melakukan politik pembersihan. Abdoel Chalid Salim terpaksa kembali ke kampungnya di Koto Gadang. Waktu itulah sepupunya, Miswar (yang juga anggota PKI dan kemudian didigulkan), memberitahukan bahwa Tan Malaka datang ke Singapura dan mendesak Abdoel Chalid Salim pergi ke sana untuk bertemu dengannya. Dalam situasi sulit Abdoel Chalid Salim berencana ke Singapura lewat Jambi dan Bagan Siapi-Api, atau lewat Pontianak, tapi urung. Akhirnya ia menyelinap ke Medan. Di sana ia menulis untuk Pewarta Deli di bawah nama pena Katjong Betawi.

Agen-agen Politiek Inlichting-dienst Belanda mencokoknya di Medan pada 12 Oktober 1927. Pada tahun itu juga ia dikirim ke Digul. Tahun 1943, menyusul serbuan si Fasis Jepang ke Indonesia, Chalid Salim dan para digulis lainnya diungsikan Belanda ke Australia. Di Melbourne ia bekerja untuk mingguan Penjuluh yang menjadi media 'NederlandschIndische propaganda' di bawah NIGIS (Netherlands Indies Government Information Services). Inilah yang disebut oleh Harry Poeze (2012) sebagai 'the strange alliance of Dutch authorities and Digoel exiles in Australia, 1943-1945'. Terkepung oleh dilema (kalau balik ke Indonesia takut dibantai Jepang), Chalid Salim memilih pergi ke Belanda, tanah air para penjajah yang sudah mendigulkannya. Kapal Belanda Volendam 'mendamparkannya' di Rotterdam pada 3 Oktober 1946.

Dalam otobiografinya, Abdoel Chalid Salim mengaku seperti berada di 'tanah airnya' sendiri karena sejak kecil sudah hidup dalam budaya Belanda. Di Belanda, Chalid bertemu Erna, seorang gadis Indonesia yang akrif dalam stichting 'Nederland helpt Indie'. Chalid dan Erna menikah di Amsterdam pada 28 Januari 1958. Negeri Eropa yang dingin benar-benar mengubah jalan hidup dan pikiran Chalid. Ia menjadi pemeluk Kristen dengan nama baptis Ignatius Franciscus Michael Salim (sering disingkat: I.F.M. Salim). Belum diperoleh keterangan kapan persisnya ia dibaptis dan di mana. Kekristenannya dicelakkannya benar dalam otobiografinya yang dibuka dengan kutipan Injil: Matheus 20 dan 16. 
Jika sudah begitu apa hendak dikata, Ranah Bundo pun mungkin akan menjauh darinya. Foto ini merekam pertemuan Chalid Salim dan keluarganya dengan Abang 'kecil'nya, Haji Agus Salim, di Amsterdam tahun 1953. Bujang yang berdiri di kiri Abdoel Chalid Salim adalah Sjahzan, adik Sutan Sjahrir. Cukup kontras gaya fashion kedua kakak beradik itu dan tentu cukup banyak cerita yang dapat dibuat tentangnya. Belum diperoleh keterangan apakah pada waktu itu Chalid sudah menyembah 'kayu berjupang' atau belum. Konon ketika belakangan Haji Agus Salim diberitahu bahwa adiknya sudah memeluk Kristen, si Abang hanya berkomentar: Baguslah sekarang dia sudah percaya kepada Tuhan. Belum ditemukan cacatan apakah sesudah menjadi umat Kristiani, I.F.M. Salim pernah lagi merasakan hangatnya udara Minangkabau, khususnya Koto Gadang.

Abdoel Chalid Salim meninggal di Belanda pada 10 Maret 1985 dan dimakamkan di Pemakaman Rijswijk Eikelenburg, Zuid-Holland. Inilah kisah seorang anak Minangkabau yang telah manuka kabilaik-nya dalam alunan riak rantau dan hilang dibawa 'angin limbubu'. Kalau ada orang Koto Gadang yang berkunjung ke Belanda, sempatkan jugalah mengunjungi pusaro anak-kemenakan yang telah tabuang jauah itu.

Kedua, Pendeta Willy Amrul (1927-2012). ${ }^{25}$ Willy Amrul memiliki nama asli Abdul Wadud Karim Amrullah (AWKA), adik seayah dari Buya Hamka, dilahirkan di Kampung Kubu, Sungai Batang, Maninjau, Agam, 7 Juni 1927. Abdul Wadud atau Willy Amrull lahir sebagai anak tunggal dari istri ketiga Abdul Karim Amrullah (Haji Rasul) yaitu Siti Hindun. Ia merupakan adik lain ibu dari Abdul Malik Karim Amrullah (HAMKA). Abdul Wadud menghabiskan masa kecilnya di Maninjau. Sebagaimana anak-anak Minangkabau lainnya, waktu kecil ia pergi ke surau di kampungnya dan pergi sekolah agama di Padang Panjang yang dikelola oleh murid-murid ayahnya. Ia meninggalkan Minangkabau pada 8

${ }^{25}$ Admin, "Willy Amrul," dalam https://id.wikipedia.org/wiki/Willy_Amrull, Diakses Tanggal 15 November 2016. Abdul Wadud Karim Amrullah (AWKA), Dari Subuh hingga Malam: Perjalanan Seorang Putra Minang Mencari Jalan Kebenaran, (Jakarta : PT. BPK Gunung Mulia, 2011), hlm. 213. 
Agustus 1941 bersama ayahnya ke Sukabumi, ketika ayahnya dibuang oleh pemerintah Hindia Belanda karena aktivitas perjuangannya.

Sepeninggal ayahnya pada 1945, Abdul Wadud berangkat ke Rotterdam dengan bekerja sebagai tukang binatu di kapal MS Willem Ruys yang berangkat dari Tanjung Priok pada Februari 1949. Selanjutnya ia meneruskan petualangan ke Amerika Serikat dan Amerika Selatan pada 1950 sebelum akhirnya memutuskan untuk menetap di San Francisco, California. Di California, Abdul Wadud mendirikan IMI (Ikatan Masyarakat Indonesia) tahun 1962. Kemudian ia menikah dengan Vera Ellen George, seorang gadis Indo, pada 6 Juni 1970 dan belakangan dikaruniai 3 orang anak. Ia juga aktif dalam kegiatan Islamic Center yang dikelola oleh para imigran Islam dari Indonesia dan negara-negara Islam lainnya di Los Angeles.

Pada tahun 1977 keluarga ini kembali ke Indonesia dan bekerja di biro perjalanan milik Hasjim Ning di Bali. Pada saat bisnis mereka bermasalah, istrinya yang mualaf kembali diajak teman-temannya untuk pergi ke gereja. Tidak itu saja, sang istri juga mengajak si suami untuk turut serta. Akibatnya mereka sering bertengkar hebat. Setelah cukup lama dalam kesulitan ekonomi, pada tahun 1981, ia setuju mengikuti agama istrinya. Pada tahun 1983, ia dibaptis oleh Pendeta Gereja Baptis Gerard Pinkston di Kebayoran Baru. Ia kembali ke Amerika Serikat tahun itu juga, menyusul istri dan anak-anaknya yang sudah lebih dahulu meninggalkan Indonesia. Tidak lama kemudian Abdul Wadud ditahbiskan menjadi pendeta di Gereja Pekabaran Injil Indonesia (GPII) (sekarang Gereja Misi Injili Indonesia/GMII) di California. Sejak itu ia lebih dikenal dengan nama Pendeta Willy Amrull.

Di Sumatera Barat, Willy Amrull dikenal sebagai Pendeta Willy. Pada tahun 1999, dirinya jadi perbincangan ramai karena Kasus Wawah yang menghebohkan masyarakat Sumbar. Pada kasus tersebut, Pendeta Willy bersama Yanuardi Koto menjadi "aktor" penting dalam upaya kristenisasi di Ranah Minang. Awalnya, Pendeta Willy memakai nama samaran Badru Amarullah, dan mengaku sebagai pengusaha dan juga orang yang berdinas di Kedutaan Besar Republik Indonesia (KBRI) di Amerika Serikat. Di Padang, Pendeta Willy tinggal di sebuah rumah yang 
dihadiahkan oleh seorang pengusaha hotel. Rumah tersebut juga berfungsi sebagai tempat berkumpulnya pendeta-pendeta muda yang akan melaksanakan misi kristenisasi di Sumatera Barat. Selama berdomisili di kota Padang, Badru Amarullah atau Pendeta Willy aktif sebagai pembina Persekutuan Kristen Sumatera Barat (PKSB), sebuah organisasi yang diketuai oleh Yanuardi Koto. Kemudian terjadilah peristiwa penculikan yang dilakukan oleh orang-orang yang dibina oleh Badru Amarullah atau Pendeta Willy dan Yanuardi Koto. Dalam peristiwa yang menghebohkan tersebut, Wawah, seorang siswa, diculik dan dibaptis lalu juga ada yang memperkosanya. Kasus tersebut kemudian disidangkan di Pengadilan Negeri Padang, sedangkan Willy Amrull sudah menghilang entah kemana. Ia meninggal di Los Angeles, California, Amerika Serikat, 25 Maret 2012 dalam usia 84 tahun.

Willy Amrul meninggalkan karya tulis otobiografi seorang Minangkabau yang menjadi pendeta di Gereja Pekabaran Injil Indonesia (GPII) di Los Angeles, California, Amerika Serikat, berjudul: Dari Subuh hingga Malam: Perjalanan Seorang Putra Minang Mencari Jalan Kebenaran, penerbit: PT. BPK Gunung Mulia, Jakarta, 2011, tebal: xi + 269 halaman. ISBN : 978-979-687985-4, peresensi: Suryadi.

Ketiga, Pendeta Akmal Sani. ${ }^{26}$ Secara historis, Minangkabau tidak bisa dipisahkan dari postulat adat "Adat basandi Syarak, Syarak basandi Kitabullah" (Tradisi bersendikan Syariat, Syariat bersendikan Kitabullah al-Qur'an dan Sunnah Rasul). Tetapi, kini Ranah Minang itu dirambah Gerakan Kristenisasi. Dengan dipelopori oleh murtadnya Akmal Sani, putera daerah asli asal Pangkalan Koto Baru, Payakumbuh, yang kini menjadi pendeta di Jakarta. Untuk memuluskan program pemurtadan di Ranah Minang, dibentuklah Persekutuan Kristen Sumatera Barat (PKSB) yang disuport dengan Kitab Injil Bahaso Minang yang pertama kali diterbitkan tahun 1996. Sebagai pendeta, aktifitas Akmal Sani cukup padat dalam acara kesaksian dan sebagai pengajar (dosen) Islamologi di berbagai gereja dan kampus (School of Ministry di Bethany, dll.).

${ }^{26}$ Ibnu Aqil D. Ghani, Pendeta Mantan Minangkabau, (Padang: LAD Rumah Muallaf Indonesia, 2016), hlm. 69-72. 
Peranan Pendeta Akmal Sani sangat besar dalam merombak Ranah Minang "Adat basandi Syarak, Syarak basandi Kitabullah" menjadi kawasan "Adat dan Syarak basandi Yesus dan Injil." Dia adalah alat propaganda sekaligus profil teladan di kalangan murtadin urang awak. Terbukti, kaset ceramah kesaksian Pendeta Akmal Sani yang menyelewengkan penafsiran ayat-ayat al-Qur'an beredar luas hampir ke seluruh nusantara. Dalam ceramahnya, Pendeta Akmal Sani mengaku bahwa sebelum jadi pendeta, dulunya dia adalah orang Islam yang memahami ajaran Islam secara mendalam, bukan Islam KTP. Lalu dia kisahkan bahwa dia meyakini ketuhanan Isa al-Masih (Yesus) setelah mengkaji al-Qur'an dengan teliti.

Bila dicermati ceramah-ceramah yang disampaikan oleh pendeta murtadin itu, jelas menunjukkan keawaman dan kedangkalan ilmunya. Misalnya, dalam membaca ayat-ayat al-Qur'an yang dibawakannya, selalu saja terdapat kesalahan yang fatal, baik tajwidnya, syakalnya maupun hafalannya, banyak kalimat yang terlewatkan. Dari bacaan yang belepotan seperti itu, tidak layak untuk disebut pakar dalam agama Islam. Bahkan, bisa jadi tidak lulus metode Iqro kalau belajar di TPA.

Ketiga, Pendeta Yanwardi Koto. ${ }^{27}$ Yanwardi berasal dari Lubuak Basuang Kabupaten Agam, dahulunya bersukukan Koto. Neneknya bernama Hj. Oemi Kalsum dan ibunya bernama Saumil Warsih, keduaduanya telah almarhum. Dalam keseharian dia menyematkan nama sukunya di belakang namanya sehingga menjadi Yanwardi Koto. Anakanaknya pun diberi nama belakang yang sama yakni Koto pula. Anakanaknya tersebut ialah Zedi Koto dan Zecha Koto, sedangkan isterinya bernama Yanthie Gouw seorang perempuan dari Manado Sulawesi Utara.

Yawardi Koto telah menjadi seorang Pendeta dan menjabat sebagai Ketua Yayasan Sumatera Barat yang berkantor di Jakarta, sebagai lembaga pencari dana dari Luar Negeri dan pengatur Misi pemurtadan. Ia akatif dalam melakukan misinya terutama sekali kepada perantau orang-orang Minangkabau di Sumatra Barat. Selain memiliki yayasan, dia juga

${ }^{27}$ Ibnu Aqil D. Ghani, Pendeta Mantan Minangkabau, op. cit., hlm. 81-83. 
mendirikan Gereja Kristen Nazarene Rantau Jakarta atau biasa disingkat GKN Rantau Jakarta. ${ }^{28}$

Gereja tersebut menggunakan simbol-simbol Minangkabau dalam melaksanakan upacara keagamaan mereka seperti menggunakan beberapa ukiran khas Minangkabau pada ruangan kebaktian mereka. Menggunakan pakaian adat Minangkabau, simbol-simbol rumah gadang, dan lain sebagainya. Gereja inilah yang menjadi tempat Yanwardi "menggembalakan domba-dombanya" yang tersesat. Termasuk di dalamnya anak dan isterinya. Yanwardi memiliki seorang kawan yakni sepasang suami isteri. Si suami juga seorang pendeta gereja di Padang. Namanya lelaki tersebut ialah Afolo Waruwu dan isterinya ialah Mei S.K. Hardjolelono. Pasangan ini bersama Yanwardi tampaknya berkawan dekat.

\section{Penutup}

Fenomena konversi agama pada masyarakat suku Minangkabau; dari Penganut Islam menjadi pemeluk Kristen dimulai sejak adanya kontak dan relasi perdagangan antara bangsa-bangsa Barat; Portugis, Belanda, Inggris dan Prancis dengan masyarakat Minangkabau dari Kerajaan Pagaruyung (1347-1825 M). Ketika Pemerintahan Kolonial Belanda mendirikan kantor dagang "VOC (Vereenigde Oostindische Compagnie)nya di Pantai Barat Padang pada tahun 1678 dan menempatkan para pegawainya yang beragama Kristen Protestan, maka sejak saat itu pemeluk Kristen sudah ada dalam kehidupan masyarakat suku Minangkabau. Proyek Kristenisasi baru dimulai sejak Inggris yang dipimpin oleh Rafles pernah menggantikan posisi Belanda menguasai Pesisir Barat Padang pada tahun 1811-1825, terbukti dengan adanya beberapa orang Missionaris yang ditugaskan oleh Kerajaan Inggris untuk melaksanakan misi kristensisasi di pulau Sumatra, mereka adalah Evans ditugaskan di Padang, Ward ditugaskan di Bengkulu dan Burton ditugaskan di Sibolga.

${ }^{28}$ Gereja Nazere lahir di Amerika Serikat pada tahun 1908, masuk ke Indonesia pada tahun 1999. Lihat: https://sites.google.com/site/jemaatshiloh/what-shappening dan http://indonazarene.org/about-us/, Diakses Tanggal 20 November 2016. 
Netherland Zending Gospel (NZG) bekerjasama dengan Pemerintah Kolonial Belanda pernah menugaskan Gutzlaff oleh untuk melakukan Kristenisasi di ranah Minang. Misinya ini belum berhasil dan ia kembali ke Batavia (Jakarta) karena di Sumatra Tengah (sebutan untuk Sumatra Barat ketika itu) sedang terjadi Perang Paderi, pada Tahun 1825-1838 yang dipimpin oleh Tuanku Imam Bonjol.

Bersamaan dengan masuknya Penjajah Belanda di ranah Minang, ikut di dalamnya para misionaris, zending, pendeta dan pastur dengan misi 2 (dua) utama, yaitu: (1) memimpin kebaktian/ peribadatan di gereja bagi pemeluk Kristen yang terdiri dari para pegawai dan serdadu Belanda, serta beberapa orang polisi pribumi yang berasal dari suku Ambon, Menado dan Jawa yang diangkat dan bekerja pada Pemerintah Kolonial Belanda, dan (2) mengajak penduduk pribumi/ masyarakat suku Minangkabau untuk berpindah agama dari Islam menjadi pemeluk Kristen, dengan berbagai cara dan tahapan. Tahapan gerakan kristenisasi ini dimulai dengan membangun Kristen Protestan Koepelkerk di Pantai Barat Padang yang dibangun gereja. Gerakan kristenisasi terlihat semakin meningkat ketika memasuki paruh kedua abad ke 19 dan abad ke 20. Secara berturut-turut dan terencana, rehabilitasi pembangunan gereja dimulai dari Bukittinggi tahun 1916-1917, Sawah Lunto tahun 1920, Padang tahun 1925 dan Payakumbuh tahun 1933. Dilanjutkan dengan membangun sarana pendidikan dan rumah sakit, unit-unit pelayanan sosial, kemanusiaan, dll, di mana pada tahun 1823 oleh Rater Paulus Jacobs, Severinus Aarts, Hermenigildus Fromm, Theodatus Van Oers dan Claudius Kok, sehingga selain Katolik dan Protestan, di Ranah Minang juga tersebar ajaran Gereja Masehi Advent Hari Ketujuh, Bethani, Pantekosta, Katedral, dan lain-lain.

Gerakan kristenisasi semakin jelas dan meningkat sejak tahun 1950an, seiring dengan adanya program transmigrasi di Obilin dan Swahlunto. Bersamaan dengan itu, misi kristenisasi juga dilakukan melalui asimilasi masyarakat Minang melalui perkawinan. Namun, pendekatan ini ditolak secara mentah-mentah oleh masyarakat Minang, bahkan menimbulkan reaksi keras dari berbagai kalangan. Meskipun demikian masih ada yang berhasil dibawanya. Pada tahun 1970-an proyek kristensisasi dilakukan dengan cara mendirikan Rumah Sakit Baptis 
Immanuel di Bukittinggi, akan tetapi misi mereka cepat tercium dan akhirnya ditolak oleh semua komponen masyarakat Minang, terutama Buya H. M. D. Dt. Palimo Kayo, mantan Ketua MUI Sumbar, Buya Mohd. Natsir, Buya Hamka, mantan Ketua MUI Pusat. Untuk menghambat gerakan kristenisasi di ranah Minang, di Bukit Tinggi telah dibangun Rumah Sakit Islam Ibnu Sina dan Rumah Sakit Immanuel diambil alih oleh pemerintah dengan mengubah nama dan statusnya menjadi Rumah Sakit Ahmad Mukhtar.

Selain melalui cara-cara tersebut, perantaraan ekonomi proyek Kristenisasi juga kerap kali dilakukan di Ranah Minang. Usaha yang dilakukan Koppasta (Koperasi Pasar Tarusan) dan Bank Lippo milik James T. Riady. Pasca gempa Sumatera Barat tahun 2009, Misionaris Kristen menggunakan bendera LSM Mitra Sejati dan Samaritan membagibagikan Alkitab yang berjumlah sekitar 180 buah dan mengajak masyarakat masuk Kristen di Korong Koto Tinggi, Kecamatan V Koto Timur, Kabupaten Padang Pariaman. Berbagai cara lainnya yang dilakukan oleh para missionaris untuk memurtadkan orang-orang Minang agar berpindah agama dari Islam ke Kristen adalah melalui perkawinan, bantuan ekonomi, hipnotis, sihir, penculikan dan pemerkosaan serta menjadi al-Qur'an dan Hadis sebagai alat kristenisasi.

Proyek kristenisasi di Sumatra Barat sudah berjalan sejak zaman penjajahan Belanda sampai dengan sekarang, dan sampai hari ini sudah tercatat sudah 623 orang Minangkabau yang sudah dikristenkan sejak tahun 2000-2005, dan sampai dengan tahun 2012 sebagaimana dilaporkan oleh Persekutuan Gereja Indonesia (PGI) bahwa orang Minangkabau yang sudah berpindah agama dari Islam menjadi pemeluk Kristen telah mencapai 30.000 jiwa yang tersebar di seluruh penjuru dunia. Dari jumlah tersebut, tercatat sudah ada 30 orang Minangkabau yang telah menjadi Pendeta dan aktif dalam proyek kristensisasi di ranah Minang dan masyarakat suku Minangkabau. Nama-nama pendeta orang Minang, di antaranya adalah : (1) Pendeta I.F.M. Salim Alias Abdoel Chalid Salim (1904-1985), ia adalah adik kandung Haji Agus Salim, Pahlawan Nasional, (2) Pendeta Willy Amrul alias Abdul Wadud Karim Amrullah disingkat AWKA (1927-2012), adik seayah dari Buya HAMKA, (3) Pendeta Akmal Sani yang sangat besar peranannya dalam merombak 
Ranah Minang "Adat basandi Syarak, Syarak basandi Kitabullah" menjadi kawasan "Adat dan Syarak basandi Yesus dan Injil," (4) Pendeta Yanwardi Koto, dari Lubuak Basuang Kabupaten Agam, (5)Pendeta Sofyan yang berasal dari Lintau, Kabupaten Tanah Datar, dll. 


\section{DAFTAR PUSTAKA}

Abid, Ahsanul. Islam Dan Muslim Dalam Pandangan Amerika, dalam http://ahsanulabid .blogspot.com/2013/01/islam-dan-muslim-dalampandangan-amerika_9.html, Diakses Tanggal 05 Maret 2014.

Abdullah, Ahmad Norma Permata (ed), Amin. Metodologi Studi Agama, (Yogyakarta: Pustaka Pelajar, 2000).

Arikunto, Ny. Suharsimi, Prosedur Penelitian; Suatu Pendekatan Praktek, Rinneka Cipta, Jakarta, 2009.

Admin, Islam Menurut Amerika (Sebuah Studi Kasus), dalam muslimdaily.net, Diakses Tanggal 05 Maret 2014.

Ali, Maulana Muhammad. Islamologi (Din al-Islam), Terjemahan, PT. (Jakarta: Ikhtiar Baru Van Hoeve, 1980).

Carrier SJ., H. The Sosiology of Religious Belonging, (London: Darton, Longman \& Todd, 2000).

Daniel, Norman. Islam and the West: The Making of an Image, (Edinburgh: Edinburgh University Press,1960), dalam google_book, 2014.

Diknas RI, Tim Penyusun. Kamus Umum Bahasa Indonesia, (Jakarta : Balai Pustaka, 2001).

Djma'an, Metodologi Penelitian Kualitatif, (Yogyakarta : Kanisius, 1999).

Gerungan, W.A. Psikologi Sosial, (Bandung: Eresco, 1980).

Harun Nasution, Islam Ditinjau Dari Berbagai Aspeknya, (Jakarta : Bulan Bintang, 1991), Juz I.

Hardjana, A.M. Penghayatan Agama: Yang Otentik dan Tidak Otentik, (Yogyakarta: Kanisius, 1993).

Hasan Ali, Ilmu Perbandingan Agama,, (Yogyakarta : al-Falah, 1995).

Hourani, Albert. Islam in European Thought (New York: Cambridge University Press, 1991), dalam google_book, 2014. 
Jalaluddin, Psikologi Agama, (Jakarta: Raja Grafindo, 1996).

Kallaf, Abdul Wahab. Kaidah-kaidah Hukum Islam, (Bandung: Risalah, 1985).

Maloeng, Lexy J. Metodologi Penelitian Kualitatif, (Bandung ; PT. Remaja Rosdakarya, 1997).

Maman, dkk., U. Metodologi Penelitian Agama; Teori dan Praktek, (Jakarta : PT. Rajawali Press, 2004).

Mar'at, Sikap Manusia, Perubahan serta Pengukurannya, (Jakarta: Ghalia Indonesia, 1981).

Max Heinrich, Change Of Heart: A Test of Some Widely Theories about Religious Conversion, dalam American Journal Of Sociologi, Volume 83, Nomor 3.

Mudzakir, Abdul Mujib \& Jusuf. Nuansa-nuansa Psikologi Islam, (Jakarta: PT. Raja Grafindo Persada, 2001).

Muhammad Noor, dkk, al-Qur'an dan Terjemahannya, (Semarang: CV. Toha Putra, 1996).

Mukti Ali, dkk., Agama Dalam Pergumulan Masyarakat Kontemporer, (Yogyakarta, Tiara Wacana, 2001).

Nazir, Mohd. Metode Penelitian, (Jakarta ; Bina Aksara, 2000).

Patton, Michael Quin. Qualitative Evolution and Reasearch Methode, (Newbury Park : Sage Publication, 1990).

Puspito, D. Hendro. Sosiologi Agama, (Yogyakarta: Kanisius, 1993).

Rodinson, Maxime. Europe and the Mystique of Islam, (London : LB. Tauris \& Co, 1988), dalam google_book, 2014.

Salim al-Mishri, Abul Asybal Ahmad bin. Fatwa-fatwa terlengkap seputar Terorisme, Jihad dan Mengkafirkan Muslim, (Jakarta: Darul Haq, 2006).

Soekanto, Soerjono. Kamus Sosiologi, (Jakarta: Royandi, 1985). 
Schleiermacher, Friedrich. Der Christliche Glaube in Samtliche Werke, Edisi Kedua, Volume 3, (Berlin, 1842).

Syamsi Ali, Muhammad. 4000 Orang Masuk Islam setiap Tahun di Amerika, dalam http://www.hidayatullah.com/read/2013/11/29/7541/ada-4ribu-orang-masuk-islam-setiap-tahun-di-amerika.html, Diakses Tanggal 05 Maret 2014.

Walgito, Bimo. Pengantar Psikologi Umum, (Yogyakarta: Andi Offset, 2007).

William James, Pengalaman-pengalaman Religius, (Yogyakarta: Penerbit Jendela, 2003).

Zakiyah Daradjat, Ilmu Jiwa Agama, (Jakarta: PT. Bulan Bintang, 2005).

Prof. Dr. H. Kurnial Ilahi, MA adalah Dosen tetap pada Fakultas Usuhuluddin Universitas Islam Negeri Sultan Syarif Kasim Riau dan Sekarang menjabat sebagai Wakil Koordinator KOPERTAIS Wilayah XII Riau Kepri. Email : kurniailahi.1953@gmail.com

Dr. H. Jamaluddin Rabain, M.Us adalah Dekan dan Dosen tetap pada Fakultas Usuhuluddin Universitas Islam Negeri Sultan Syarif Kasim Riau. Email: jamaluddin@uin-suska.ac.id

Suja'i Sarifandi, M.Ag adalah Dosen tetap pada Fakultas Usuhuluddin Universitas Islam Negeri Sultan Syarif Kasim Riau. Email: suja'i.sarifandi@uin-suska.ac.id 